\title{
Characterisation of Volatile Compounds and Composition of Milk of Kilis Goats Reared at Two Different Locations
}

\author{
Aylin Celile Oluk ${ }^{1 *}$, Ugur Serbester ${ }^{2}$, Murat Reis Akkaya ${ }^{3}$ and Oya Berkay Karaca ${ }^{4}$ \\ ${ }^{I}$ Eastern Mediterranean Agriculture Research Institute, Ministry of Food Agriculture \\ and Livestock, 01321 Adana, Turkey \\ ${ }^{2}$ Deptartment of Animal Science, Faculty of Agriculture, Cukurova University, 01903 \\ Bahce, Adana, Turkey \\ ${ }^{3}$ Deptartment of Food Engineering, Faculty of Engineering, Alpaslan Turkes Science \\ and Technology University, Adana, Turkey \\ ${ }^{4}$ Karatas School of Tourism and Hotel Management, Cukurova University, 01903 Bahce, \\ Adana, Turkey
}

\section{A B S T R A C T}

Various factors such as species, breeds, lactation stage and location affect milk composition. We evaluated the composition of Kilis goat milk in two different seasons on the basis of alcohols, ketones, aldehydes, esters, indoles, carboxylic acids, aromatic hydrocarbons and terpenes. Milk samples were collected at the early and late lactation periods from Hatay and Kilis, Turkey. During both periods, the goats consumed a diversity of plant species. Milk collected from Kilis had $15.27-16.10 \%$ total solids, $5.70-6.50 \%$ fat and $4.80-5.10 \%$ protein. The lactose content did not differ significantly between milk samples from the two locations $(3.90-4.20 \%)$. Total unsaturated fatty acid levels were significantly higher than total saturated fatty acid contents, irrespective of the lactation period $(\mathrm{p}<0.05)$. Milk from Hatay was high in saturated

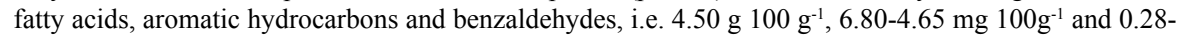
$0.70 \mathrm{mg} 100 \mathrm{~g}^{-1}$, respectively. Throughout the lactation period, the levels of total solids, fat, protein, saturated and unsaturated fat, alcohol, ketones, esters and carboxylic acid increased, while indole, terpene, aromatic hydrocarbon and aldehyde contents decreased.

\begin{tabular}{l} 
Article Information \\
Received 21 May 2019 \\
Revised 30 July 2019 \\
Accepted 23 April 2020 \\
Available online 14 May 2021 \\
Authors' Contribution \\
\hline ACO designed and performed \\
experiments, analysed data and wrote \\
the paper. US and MRA performed \\
experiments. OBK analysed data. \\
Key words \\
Goat milk, Lactation, Milk \\
composition, Volatile compounds, \\
Indoles
\end{tabular}

\section{INTRODUCTION}

$\mathrm{I}^{\mathrm{n}}$ $\mathrm{n}$ recent years, goat breeding has become more profitable than cattle and sheep breeding due to changes in global climate and precipitation regimes and increased soil salinity (Silanikove, 2000). Goats are more adaptable to arid environments because of their feeding behaviour, the digestion of high-fibre fodder in the rumen, their water metabolism and their capacity to store and later mobilise body reserves; they are therefore capable of adjusting the widely varying feeding situations (Morand-Fehr, 1991). About 500,000 domestic goats of the total 11 million goats in Turkey are Kilis goats. This breed is endemic and used in the southeastern regions (Kilis, Gaziantep, Hatay and Sanlıurfa) of Turkey (Daskiran et al., 2018). It has a black and brown fur coloration and long pendulous ears; its hair is straight, long and coarse. Animas of this breed are seasonal

Corresponding author: celileaylin.oluk@tarimorman. gov.tr; aylinoluk@yahoo.com 0030-9923/2021/0004-1279 \$ 9.00/0

Copyright 2021 Zoological Society of Pakistan breeding animals for both meat and milk production and endangered genetic resources in Turkey (Tasdemir et al., 2011). The Kilis goat is the most important domestic goat breed for high milk yield; it is highly resistant to adverse environmental conditions and diseases (Anonymous, 2018). Milk yield and lactation time vary among different studies: $300-400 \mathrm{~kg}$ per lactation and 210-260 days (Iriadam, 2007), 250-400 kg and250-300 days (Cetin et al., 2009). According to the communiqué about race and line registration of domestic animals in Turkey, on average, milk yield is $217.4 \mathrm{~kg}(70.3-269.6 \mathrm{~kg})$ and lactation time is 228 days (178-257 days) (Anonymous, 2018; Agaoğlu and Ertugrul, 2012).

Kilis goats reared in Hatay and Kilis are indigenous breeds and the most important source of milk for the rural population (Aslantas et al., 2005). The area contains meadows (16\%), shrubland (12\%) and forests $(6 \%)$ and represents the transition area between the Southeast Anatolian steppe and the Mediterranean vegetation (maki), with Mediterranean vegetation being dominant in Hatay (Anonymous, 2019). Climatic and environmental conditions affect the aroma of dairy products. For example, the milk 
of animals grazing in meadows in a dry environment and at high elevations, rich in dicotyledon plants, has a more fruity and dried taste (Martin et al., 2005).

Milk composition varies among breeds, feeds, lactation stages, seasons, etc. (Silanikove et al., 2010). Goat milk contains twice as many short- and mediumchain fatty acids than cow milk (Raynal-Ljutovac et $a l ., 2008)$. It also has a stronger flavour and aroma than other types of milk. According to previous studies, the branched and short-chain fatty acids (FAs) with less than 11 carbon atoms, such as caprylic, capric and caproic FAs, are responsible for the typical "goaty" aroma (Ha and Lindsay, 1993; Salles et al., 2002; Verruck et al., 2019). The $\beta$-oxidation of PUFA could increase the amount of degradation products such as straight-chain aldehydes and ketones, which may be converted to alcohols, forming volatile components (Cais-Sokolinska et al., 2015).

Goat milk protein is more digestible for humans than cow milk protein and has a lower amount of $\alpha_{1}$-casein (Costa et al., 2014). The casein micelles from goat milk are different from those of cow milk; goat milk has a low resolution, thermal stability and sedimentation rate, a high cold solubility of $\beta$-casein, a small micelle size and high calcium and phosphorus levels (Haenlein, 2004). Few studies have focused on the effects of foodstuff on goat milk composition, especially in terms of volatile compounds (Muelas et al., 2018), but no scientific data is available regarding the effects of different locations and lactation periods on the volatile profile of goat milk. In this context, we aimed to describe the changes in the composition of Kilis goat milk during the lactation period and to evaluate the influences of location and lactation periods on fatty acid and volatile profiles of the milk of Kilis goats.

\section{MATERIALS AND METHODS}

Milk of Kilis goats was collected from two separate locations (Kilis and Hatay cities) in two different periods. Kilis is located in the transition zone between the Mediterranean and Southeast region ( $36^{\circ} 42^{\prime} 59.3136$ and $\left.37^{\circ} 6^{\prime} 52.7832^{\prime \prime}\right)$ at an average elevation of $680 \mathrm{~m}$ above sea level. Hatay is the most southern province of Turkey ( $36^{\circ} 0^{\prime} 47.1168^{\prime \prime}$ and $\left.36^{\circ} 7^{\prime} 20.1684^{\prime \prime}\right)$ and situated at an average elevation of $450 \mathrm{~m}$ above sea level. Milk samples (early lactation period) were collected from April 10 to 20 in Kilis and from 20 to 30 April in Hatay. Late-lactation samples were taken from October 15-20. The samples were collected from 16 Kilis goats, with three samples at regular intervals of 7 days. The milk samples were combined to obtain two samples per period, divided into two parts and immediately frozen at $-18^{\circ} \mathrm{C}$.
A Fourier transform infrared milk analyser (Milkoscan FT 120, FOSS Electric, Hillerød, Denmark) was used for determination of total solids, protein, fat, total saturated (SFA) and unsaturated (UFA) fatty acids, total monounsaturated fatty acids (MUFA)and polyunsaturated fatty acids (PUFA). The amounts of SFA, UFA, MUFA and PUFA were expressed as g FA/100 g milk. Volatile compounds of the goat milk samples were analysed via static headspace solid-phase micro extraction (SPME), using a gas chromatography-mass spectrometry system (Shimadzu Corporation, Kyoto, Japan) (Hayaloglu et al., 2007). A duplicate 3.0-g portion of the sample was then placed in a $15-\mathrm{mL}$ vial, followed by $10 \mu \mathrm{L}$ of internal standard containing $81 \mathrm{mg} / \mathrm{kg}$ of 2-methyl-3-heptanone in methanol (Sigma-Aldrich Co. USA) and allowed to equilibrate at $40^{\circ} \mathrm{C}$ for $30 \mathrm{~min}$. Essentially, extraction is achieved by injecting a $2-\mathrm{cm} 50 / 30 \mu \mathrm{m}$ divinyl benzenecarboxen-polydimethylsiloxane (DVB/CAR/PDMS) fibre (Supelco, Bellefonte, PA, USA) into the vial and exposing it to the headspace for $30 \mathrm{~min}$ at $40^{\circ} \mathrm{C}$. The fibre was positioned at 3.0 scale units in each run. Desorption of the extracted volatiles was carried out in a Shimadzu GC2010 gas chromatography - QP-2010 mass spectrometry system (Shimadzu Corporation, Kyoto, Japan), run in splitless mode. During desorption, the fibre remained in the injector for $2 \mathrm{~min}$ at a temperature of $250^{\circ} \mathrm{C}$, with helium as carrier gas at a flow rate of $1.0 \mathrm{~mL} / \mathrm{min}$. The volatile compounds were separated in a DB-Wax column $(60 \mathrm{~m} \times 0.25 \mathrm{~mm} \times 0.25 \mathrm{um} ; \mathrm{J}$ and $\mathrm{W}$ Scientific, Folsom, CA, USA). The oven temperature was held at $40^{\circ} \mathrm{C}$ for 2 min (desorption period), then increased at $5^{\circ} \mathrm{C}$ per min to $70^{\circ} \mathrm{C}$ and held for $1 \mathrm{~min}$. The temperature was then raised at $10^{\circ} \mathrm{C}$ per min to $240^{\circ} \mathrm{C}$ to provide a run time of 30 $\mathrm{min}$. The mass spectrometer was set to record at 33 to 450 amu (threshold 1,000) at a sampling rate of $1.11 \mathrm{scans} / \mathrm{s}$. The volatile compounds were identified by calculation of the retention index (RI) of each compound, using an $n$-alkane series $\left(\mathrm{C}_{8}\right.$ to $\left.\mathrm{C}_{20}\right)$ under the same conditions. The peak identifications were based on comparison of the mass spectra of unknown compounds with those in the Wiley 7 ( $7^{\text {th }}$ edition) and NIST/EPA/NIH 02 mass spectral libraries. Identifications were also confirmed by comparing retention times with reference standards when available. About 30 authentic standard compounds (Sigma chemical Co., St. Louis, MO) were used to confirm volatiles in the obtained cheese samples. The RI values were also compared with those described in the literature, determined under the same conditions for matching the compounds. The results were calculated by comparison of the peak area of the internal standard and the unknown compounds. Each compound was expressed as $\mathrm{mg} / 100 \mathrm{~g}$ of sample. 


\section{Statistical analysis}

Variance analysis was performed by ShapiroWilk and Bartlett's tests. The fixed effects were breed, lactation stage and breed $\mathrm{x}$ lactation stage interaction. The covariance structure was autoregressive order 1 , and the degrees of freedom were adjusted by the Kenward-Rogers method. Mean separation of significant effects $(\mathrm{P}<0.05)$ was conducted by SAS (1999). Least squares means and SEM are reported for all data.

\section{RESULTS AND DISCUSSION}

\section{Milk composition}

At the late lactation, the levels of total solids, fat, protein, total UFA, SFA, MUFA and PUFA ratios in the goat milk were increased in both locations (Table I); this result is in agreement with previous findings (Mestawet et al., 2012; Chen et al., 2017). Total solids, fat, protein, total UFA, SFA and MUFA contents were highest in Kilis at early lactation. The total solid content of milk from Kilis was similar to the $13.88-16.27 \%$ reported by Mestawet et al. (2012), but lower than the $17.5 \%$ observed by Casey and Van Niekerk (1988). The fat and protein contents ranged between $4.2-6.5 \%$ and $3.6-5.1 \%$, respectively. The fat content was lower than that observed in a study in South Africa with Boer goat milk, but similar to the findings of other studies, which reported7.5-6.1\% fat and 4.3-5\% protein, respectively (Greyling et al.,2004; Mestawet et al., 2012). These differences are most likely due to different environmental conditions and feeding strategies. At late lactation, the milk components in milk from Hatay were more highly concentrated than in milk from a cross breed in Ethiopia, with $13.88 \%$ total solids, $3.65 \%$ fat and $4.08 \%$ protein (Mestawet et al., 2012); milk from Maltese goats from Italy had relatively low levels of protein (3.4\%) and fat (3.5\%) (Carnicella et al., 2008). The protein and fat compounds of milk are significantly affected by the season, age and nutrition (Mestawet et al., 2012). Goats prefer leaves over stems, thick stems over thin ones and the protein parts over the carbohydrate parts (Morand-Fehr, 1991). In the early lactation period, the high protein content of goat milk from Kilis may be a result of the high protein level of the forage in this region. The lactose contents of milk samples from both regions were lower than the values found by Guo et al. (2004) with $4.47 \%$ and Prasad et al. (2005), who reported levels of well above $5.5 \%$.

Milk FA composition is affected by rumen biohydrogenation and $\Delta 9$-desaturase enzyme conversion (C18:0 into C18:1, Bauman and Griinari, 2003), but considerable changes in the milk fat composition can be achieved by dietary changes (Liu et al., 2016). The total SFA content of goat milk was higher in milk from Hatay location than in milk from Kilis in the late lactation period. Differences in the diet can lead to differences in the saturated and unsaturated fatty acid profiles of milk (Calderon et al., 1984). We observed a significant difference $(\mathrm{P}<0.05)$ between total UFAs and SFA content in both early and late lactation periods. The mean contents of total SFAs (3.00-4.50 $\left.\mathrm{g} 100 \mathrm{~g}^{-1}\right)$ were comparable to the values found in milk from Saanen or Alpine goats (3.34-

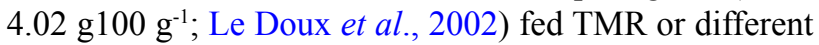
level of forages. However, Alpine goats raised in feedlots provided milk with low total SFA contents (1.08-2.68 g100 $\left.\mathrm{g}^{-1}\right)$ (Bernard et al., 2005).

Unsaturated fatty acids are the precursors of dairy aromas and are reduced by microbial enzymes in the rumen (Martin et al., 2005). Total UFAs showed the

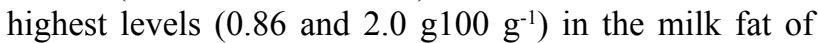
goats at different lactation stages $(\mathrm{P}<0.05)$; the total UFA levels were higher in milk from Kilis compared to milk from Hatay (Fig. 1), irrespective of the lactation period. This suggests that the proportion of unsaturated fatty acids is higher in milk from high elevations than in milk from low elevations. The concentration of unsaturated fatty acids in goat milk varies with fodder plants (Alvarenga et al., 2015). The UFA content of Kilis goat milk were higher than those of Saanen and Swedish Landrace goat milk samples. Yurcenko et al. (2018) reported $25.80 \mathrm{~g} 100 \mathrm{~g}-1^{-1}$ UFA in the total FA of Saanen goat fat, equivalent to $0.86 \mathrm{~g}$ $100 \mathrm{~g}^{-1}$ UFA in the total FA of goat milk. These differences might be due to the higher amount of dicotyledon species in the diet of Kilis goats.

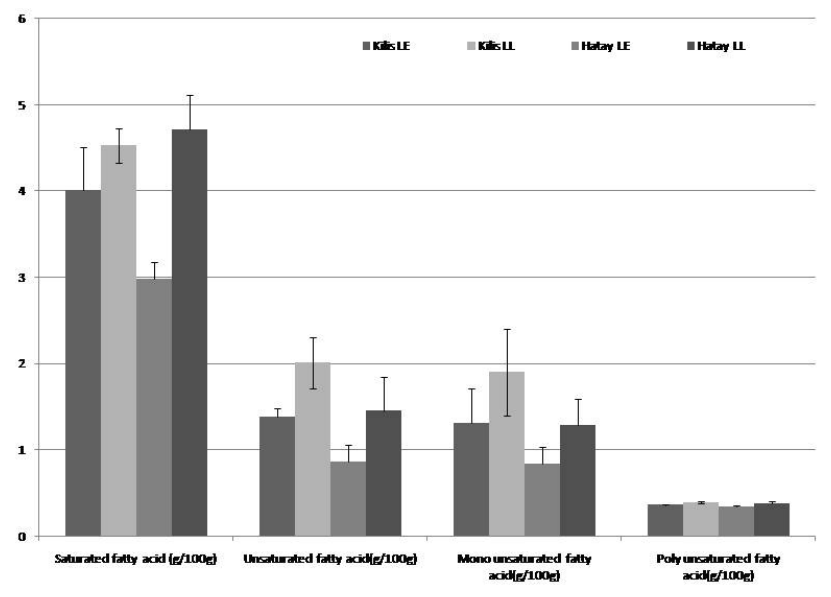

Fig. 1. Change of saturated and unsaturated fat content during laction period.

The total MUFA level in goat milk from both

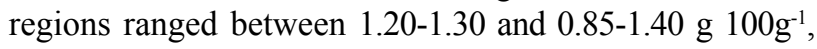


respectively. A low monounsaturated fatty acid level in caprine milk (0.37-0.50 g $\left.100 \mathrm{~g}^{-1}\right)$ has been determined by Alonso et al. (1999), while Talpur et al. (2009) have

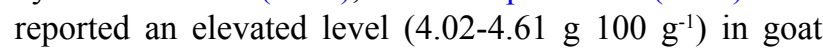
milk fat. There were no significant differences $(\mathrm{P}>0.05)$ in the total PUFAs of goat milk between the two locations and lactation periods, similar to the findings of Talpur et al. (2009) for two local breeds (Kamori and Pateri) in Pakistan. Ruminant milk fat consists of $65-70 \%$ SFA, $25-$ 30\% MUFA and 5-10\% PUFA (Schwendel et al., 2014).

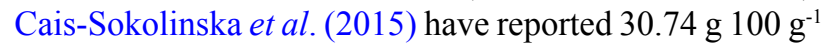
MUFA in the total FA of goat fat, equivalent to $1.03 \mathrm{~g} 100$ $\mathrm{g}^{-1}$ MUFA in the total FA of goat milk.

Throughout the lactation stages, the milk components showed high variations in milk from Hatay at the late lactation period. The levels of total solids, fat, protein, saturated and unsaturated fatty acids were significantly higher $(\mathrm{P}<0.05)$ in the late lactation period than in the early lactation period; similar results have been described by Guo et al. (2004). Dry matter levels were highest at the end of the lactation period. Based on the lactation curve of goats, in the early lactation period, the total solid content is low, along with a high milk quantity. The opposite pattern was observed for the late lactation period.

The differences in the lactose contents of the milk from the same goat breed, but different locations, were not statistically significant $(\mathrm{P}>0.05)$. In both locations, lactose contents were high in the early lactation period, with subsequent decreases; this has also been observed by Prasad et al. (2005). The protein and total PUFA concentrations increased throughout the lactation period in both locations due to increasing herbage sugar content because of the accumulation of photosynthesis products (Avondo et al., 2008).

\section{Volatile compounds of goat milk from different locations}

All volatile compounds of milk from Kilis and Hatay are shown in Table II. A total of 58 volatile compounds were identified, including 4 indoles, 7 terpenes, 8 ketones, 5 aldehydes, 8 carboxylic acids, 7 alcohols, 18 aromatic hydrocarbons and 2 esters. Table III also shows the statistical evaluation of the differences in lactation periods and location in terms of the volatile components. Of the 58 components, 22 were present in both lactation periods and in the milk of both locations. According to Muelas et al. (2018), ketones (sweet, buttery and creamy flavours), acids and alcohols (alcoholic and floral-fruity notes) in fermented dairy products have different aroma perceptions. Acetic and lactic acids contribute to the acidic aroma, while butanoic, hexanoic and octanoic acids are responsible for the goaty and cheesy aroma. The major volatile compounds detected in Kilis goat's milk were $\alpha$ - pinene, dl-limonene, cymene, capric acid, 2- octanol and 4-nonanol, irrespective of the location. The lactation period affected the amounts of volatiles in goat milk. While the amounts of terpenes, aldehyde and aromatic hydrocarbons significantly decreased during the lactation period, indoles, ketones, carboxylic acids and alcohols increased for both locations $(\mathrm{P}<0.05)$.

The amount of 3-methylindole (skatole), derived from tryptophan degradation, in milk from Hatay was higher than that in milk from Kilis in both lactation periods

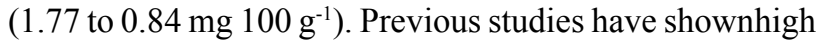
amounts of skatole in the milk of grazing animals (Prache et al., 2005; Schreurs et al., 2008). In the late lactation period, 2-3-N-phenylimino indole and $1 \mathrm{H}$-Indole were not detected.

The terpene content did not significantly differ between the two lactation periods (17.68 versus 8.58 $\mathrm{mg} / 100 \mathrm{~g})$ in milk from Kilis, but decreased significantly $(P<0.05)$ from early to late lactation $(27.36$ versus 11.76 $\mathrm{mg} / 100 \mathrm{~g})$ in milk from Hatay location. The terpenes $\alpha$-pinene, dl-limonene and $\beta$-phellandiene were the most abundant terpenes, irrespective of the location and lactation period $(\mathrm{P}<0.01)$. According to a previous study, higher herbage intake modifies the digestive and metabolic processes (Fedele et al., 2005), and terpenes can be used to determine the geographical origin of animals that graze pastures (Prache et al., 2005). The terpene contents of the milk samples from both locations varied, mainly because the plant species Geranium tuberosum, Arum dioscoridis, Asparagus acutifolius, Asphodelus aestivus, Gynandriris sisyrinchium and Ophrys lutea are found in Kilis grassland, while Muscari babachii, Scilla autumnalis, Gladiolus italicus, Orchis simia and Cephalanthera longifolia are more common in Hatay. Boutoial et al. $(2012,2013)$ have observed that addition of aromatic plants, such as rosemary and thyme, to goat diets increased the levels of PUFAs, protein, dry matter and lactose. Sant'Ana et al. (2019) have detected higher $\alpha$-pinene concentrations in goat milk obtained from goats grazing native pastures of a semiarid region of Brazil compared with milk from animals kept under confinement.

In milk from Kilis, the ketone levels increased significantly $(P<0.05)$ from early lactation $(1.65 \mathrm{mg} / 100$ g) to late lactation $\left(1.76 \mathrm{mg} 100 \mathrm{~g}^{-1}\right)$, mainly because of the conversion of secondary alcohols to methyl ketones. 2-octanone, 4-nonanone, furanone and 3-buten-2-one compounds were found in the goat milk in both lactation period. Of these, 2-octanone, which has a fruity aroma (Fedele et al., 2005), was detected in higher concentrations in milk from the lactation period and from Kilis. The fat content seems to have an influence on the concentration of ketones (Vazquez-Landaverde et al., 2005), and in our 
Table I. The changes in milk composition of Kilis goat breed from Hatay and Kilis locations during lactation period.

\begin{tabular}{|c|c|c|c|c|c|c|c|c|}
\hline & \multicolumn{2}{|c|}{ Kilis } & \multicolumn{2}{|c|}{ Hatay } & \multirow[t]{2}{*}{ SEM } & \multirow[t]{2}{*}{ Location } & \multirow{2}{*}{$\begin{array}{l}\text { Lactation } \\
\text { period }\end{array}$} & \multirow{2}{*}{$\begin{array}{l}\text { Location } \times \text { Lactation } \\
\text { period }\end{array}$} \\
\hline & $\overline{\mathbf{E L}}$ & $\mathbf{L L}$ & $\overline{\mathbf{E L}}$ & $\mathbf{L L}$ & & & & \\
\hline Total solids (\%) & 15.27 & 16.10 & 12.70 & 16.30 & 1.11 & 0.31 & 0.07 & 0.25 \\
\hline Fat $(\%)$ & 5.70 & 6.50 & 4.20 & 6.50 & 1.03 & 0.53 & 0.18 & 0.50 \\
\hline Protein $(\%)$ & 4.80 & 5.10 & 3.60 & 5.10 & 0.37 & 0.13 & 0.03 & 0.14 \\
\hline Lactose $(\%)$ & 4.20 & 3.90 & 4.30 & 4.00 & 0.18 & 0.44 & 0.11 & 0.92 \\
\hline Total UFA (g100g $\left.\mathrm{g}^{-1}\right)$ & 1.30 & 2.00 & 0.86 & 1.60 & 0.34 & 0.27 & 0.06 & 0.94 \\
\hline Total SFA(g100g-1) & 4.00 & 4.30 & 3.00 & 4.50 & 0.87 & 0.65 & 0.32 & 0.47 \\
\hline Total MUFA (g100g-1) & 1.20 & 1.30 & 0.85 & 1.40 & 0.24 & 0.15 & 0.04 & 0.96 \\
\hline Total PUFA (g100g $\left.{ }^{-1}\right)$ & 0.30 & 0.43 & 0.35 & 0.40 & 0.03 & 0.68 & 0.14 & 0.74 \\
\hline
\end{tabular}

UFA, Unsaturated fatty acid; SFA, Saturated fatty acid; MUFA, Monounsaturated fatty acid; PUFA, Polyunsaturated fatty acid; EL, Early lactation; LL, Late lactation, SEM, Standard error of the mean.

Table II. All volatiles compounds $\left(\mathrm{mg} 100 \mathrm{~g}^{-1}\right.$, mean $\left.\pm \mathrm{SD}\right)$ during lactation period $(\mathrm{df}=9)$ in Kilis breed goat milk from Hatay and Kilis.

\begin{tabular}{|c|c|c|c|c|c|}
\hline Compounds & RI & HEL & KEL & HLL & KLL \\
\hline \multicolumn{6}{|l|}{ Carboxcylic acid } \\
\hline Acetic acid & 1467 & nd & nd & $0.052 \pm 0.01 \mathrm{~b}$ & $0.407 \pm 0.02 \mathrm{a}$ \\
\hline Benzoic acid & 1160 & $0.261 \pm 0.02 \mathrm{c}^{*}$ & $0.262 \pm 0.03 \mathrm{c}$ & $0.504 \pm 0.02 \mathrm{a}$ & $0.305 \pm 0.03 b$ \\
\hline Octanoic acid & 2083 & nd & $0.990 \pm 0.03 \mathrm{a}$ & $0.103 \pm 0.04 \mathrm{c}$ & $0.220 \pm 0.02 b$ \\
\hline Caproic acid & 1850 & nd & $0.272 \pm 0.03$ & nd & nd \\
\hline Hexadecanoic acid & 1951 & $0.013 \pm 0.02$ & nd & nd & nd \\
\hline Capric acid & 1809 & $0.346 \pm 0.04 \mathrm{~d}$ & $1.478 \pm 0.02 \mathrm{a}$ & $0.686 \pm 0.04 \mathrm{~b}$ & $0.567 \pm 0.02 \mathrm{c}$ \\
\hline Tetradecanoic acid & 1748 & nd & nd & nd & $0.078 \pm 0.02$ \\
\hline Lauric acid & 1554 & nd & $0.052 \pm 0.03$ & nd & nd \\
\hline \multicolumn{6}{|l|}{ Alcohols } \\
\hline Ethanol & 931 & $11.457 \pm 0.09 \mathrm{~d}$ & $20.913 \pm 0.06 \mathrm{c}$ & $25.242 \pm 0.06 b$ & $28.368 \pm 0.05 \mathrm{a}$ \\
\hline 2-Octanol & 981 & $13.890 \pm 0.04 \mathrm{c}$ & $16.002 \pm 0.04 b$ & $20.541 \pm 0.04 \mathrm{a}$ & $20.560 \pm 0.04 \mathrm{a}$ \\
\hline 4-Nonanol & 1076 & $19.156 \pm 0.04 \mathrm{c}$ & $21.892 \pm 0.04 b$ & $28.405 \pm 0.04 b$ & $28.425 \pm 0.03 \mathrm{a}$ \\
\hline 2-Ethyl-1-hexanol & 1484 & $0.032 \pm 0.01$ & nd & nd & nd \\
\hline 1-Butanol & 1137 & $0.022 \pm 0.01$ & nd & nd & nd \\
\hline Fluoren-9-ol & 1108 & $0.051 \pm 0.01$ & nd & nd & $0.040 \pm 0.01$ \\
\hline 1,4-Butanediol & 1252 & $0.034 \pm 0.01$ & nd & nd & nd \\
\hline \multicolumn{6}{|l|}{ Indoles } \\
\hline 3-methylindole (skatole) & 1070 & $0.835 \pm 0.03 b$ & $1.765 \pm 0.02 \mathrm{a}$ & $0.255 \pm 0.03 b$ & $0.808 \pm 0.04 b$ \\
\hline N-ethyl-1,3-dithioisoindoline & 1617 & $7.535 \pm 0.20 \mathrm{a}$ & $1.092 \pm 0.05 b$ & $0.753 \pm 0.02 \mathrm{c}$ & $1.467 \pm 0.02 b$ \\
\hline 2-3-N-phenylimino indole & 1085 & $0.160 \pm 0.02$ & nd & nd & nd \\
\hline 1H-Indole & 1257 & $0.038 \pm 0.02 b$ & $0.190 \pm 0.03 \mathrm{a}$ & nd & nd \\
\hline \multicolumn{6}{|l|}{ Aromatic hydrocarbon } \\
\hline Benzene, ethenylmethyl & 1833 & $1.660 \pm 0.50 \mathrm{~b}$ & $3.390 \pm 0.20 \mathrm{a}$ & $1.304 \pm 0.60 \mathrm{c}$ & $0.568 \pm 0.40 \mathrm{~d}$ \\
\hline 1-ethenyl-3-ethyl- benzene & 1145 & $3.858 \pm 0.30 \mathrm{a}$ & $3.145 \pm 0.60 \mathrm{~b}$ & $1.786 \pm 0.04 \mathrm{c}$ & $0.400 \pm 0.20 \mathrm{~d}$ \\
\hline 1-ethenyl-4-ethyl- benzene & 1132 & $1.790 \pm 0.02 b$ & $2.010 \pm 0.02 \mathrm{a}$ & $1.015 \pm 0.02 \mathrm{c}$ & $0.540 \pm 0.04 \mathrm{~d}$ \\
\hline
\end{tabular}




\begin{tabular}{|c|c|c|c|c|c|}
\hline Compounds & RI & HEL & KEL & HLL & KLL \\
\hline \multicolumn{6}{|l|}{ Aromatic hydrocarbon } \\
\hline Cyclopropylcarbinol & 1148 & nd & nd & $0.217 \pm 0.01 b$ & $0.670 \pm 0.03 \mathrm{a}$ \\
\hline Cyclobutanol & 1252 & $0.105 \pm 0.02 b$ & nd & $0.119 \pm 0.02 b$ & $0.293 \pm 0.03 \mathrm{a}$ \\
\hline 2,4,6-Cycloheptatrien-1-one & 1106 & $0.340 \pm 0.02 b$ & $0.072 \pm 0.04 \mathrm{c}$ & $0.690 \pm 0.03 \mathrm{a}$ & nd \\
\hline Ethylbenzene & 843 & $0.016 \pm 0.01 \mathrm{~b}$ & $0.295 \pm 0.04 \mathrm{a}$ & nd & nd \\
\hline o-Xylene & 1151 & $0.028 \pm 0.02$ & nd & nd & nd \\
\hline p-Xylene & 1149 & $0.031 \pm 0.01$ & nd & nd & nd \\
\hline 3-O-5,7,3',4'-tetra o-methylquercetin & 1079 & $0.019 \pm 0.02$ & nd & nd & nd \\
\hline $4,8,9 \mathrm{~b}$-Triazacyclopenta phenalene & 1276 & $0.331 \pm 0.02 \mathrm{a}$ & $0.293 \pm 0.02 \mathrm{a}$ & $0, .180 \pm 0.03 b$ & nd \\
\hline Benzenesulfonylchloride & 1150 & $0.122 \pm 0.02 b$ & $0.018 \pm 0.01 \mathrm{c}$ & $0.035 \pm 0.02 \mathrm{c}$ & $0.250 \pm 0.03 \mathrm{a}$ \\
\hline 2-5-thiazolyl thyocyanate & 935 & nd & nd & $0.323 \pm 0.03 \mathrm{a}$ & $0.170 \pm 0.02 b$ \\
\hline 1-allyl-2,8-dimethoxy-9H-carbazole & 1092 & $0.267 \pm 0.02 \mathrm{a}$ & $0.155 \pm 0.04 b$ & nd & $0.138 \pm 0.02 b$ \\
\hline 2-Chloro-4-6-pyrimidine & 1221 & $0.063 \pm 0.02 \mathrm{a}$ & nd & $0.042 \pm 0.02 \mathrm{a}$ & nd \\
\hline 1,3-diethenyl & 1226 & $0.562 \pm 0.02 \mathrm{a}$ & $0.125 \pm 0.04 b$ & $0.037 \pm 0.02 \mathrm{c}$ & $0.025 \pm 0.02 \mathrm{c}$ \\
\hline 3-Phenylcyclopentene & 981 & $0.043 \pm 0.03 \mathrm{a}$ & $0.022 \pm 0.04 b$ & nd & nd \\
\hline Furanone & 1530 & $0.027 \pm 0.04 b$ & nd & $0.013 \pm 0.01 \mathrm{c}$ & $0.080 \pm 0.02 \mathrm{a}$ \\
\hline 5-Ethylindan & 1177 & $0.062 \pm 0.02 \mathrm{a}$ & $0.025 \pm 0.01 \mathrm{c}$ & $0.041 \pm 0.01 \mathrm{~b}$ & nd \\
\hline Methoxy-phenyl- /oxime & 1115 & $0.305 \pm 0.01 \mathrm{c}$ & nd & $0.691 \pm 0.02 b$ & $1.195 \pm 0.05 \mathrm{a}$ \\
\hline \multicolumn{6}{|l|}{ Esters } \\
\hline Hexanoic acid ethyl ester & 905 & nd & $0.527 \pm 0.03$ & nd & nd \\
\hline Decanoic acid ethyl ester & 1823 & $0.037 \pm 0.04 \mathrm{c}$ & $0.572 \pm 0.03 \mathrm{a}$ & nd & $0.152 \pm 0.02 b$ \\
\hline \multicolumn{6}{|l|}{ Terpenes } \\
\hline Styrene & 1273 & $0.705 \pm 0.01 b$ & $0.750 \pm 0.01 \mathrm{~b}$ & $0.247 \pm 0.02 \mathrm{c}$ & $1.003 \pm 0.01 \mathrm{a}$ \\
\hline $\begin{array}{l}\text { 3-Isopropoxy-1,1,1,7,7,7-hexam- } \\
\text { ethy1-3,5,5, tristetrasiloxane }\end{array}$ & 1400 & $0.257 \pm 0.02 \mathrm{a}$ & nd & $0.071 \pm 0.01 \mathrm{c}$ & $0.150 \pm 0.01 \mathrm{~b}$ \\
\hline Silanediol & 1442 & $0.283 \pm 0.02 \mathrm{a}$ & $0.152 \pm 0.03 \mathrm{~b}$ & $0.070 \pm 0.02 \mathrm{c}$ & nd \\
\hline$\alpha$-iron & 1191 & $0.103 \pm 0.02 b$ & $0.248 \pm 0.02 \mathrm{a}$ & $0.052 \pm 0.02 \mathrm{c}$ & $0.030 \pm 0.01 \mathrm{c}$ \\
\hline \multicolumn{6}{|l|}{ Ketones } \\
\hline 2-Octanone & 964 & $0.575 \pm 0.03 \mathrm{c}$ & $0.560 \pm 0.01 \mathrm{c}$ & $0.727 \pm 0.05 b$ & $0.910 \pm 0.03 \mathrm{a}$ \\
\hline 4-Nonanone & 1076 & $0.249 \pm 0.02 \mathrm{~d}$ & $0.355 \pm 0.04 \mathrm{c}$ & $0.727 \pm 0.04 \mathrm{a}$ & $0.657 \pm 0.02 b$ \\
\hline 2-Propanone & 1201 & nd & nd & $0.047 \pm 0.02$ & nd \\
\hline 2-Heptanone & 1175 & $0.406 \pm 0.02 b$ & $0.512 \pm 0.03 \mathrm{a}$ & nd & $0.170 \pm 0.02 \mathrm{c}$ \\
\hline 2-phenyl-3,7-dimethyl-octane & 1207 & $0.026 \pm 0.02$ & nd & nd & nd \\
\hline Ethanone & 985 & $0.015 \pm 0.02$ & nd & nd & nd \\
\hline 3-Buten-2-one & 1014 & $0.199 \pm 0.01 \mathrm{a}$ & $0.178 \pm 0.02 \mathrm{a}$ & nd & $0.028 \pm 0.03 b$ \\
\hline 2-Methylindanone & 1118 & $0.041 \pm 0.02 \mathrm{a}$ & $0.053 \pm 0.02 \mathrm{a}$ & nd & nd \\
\hline \multicolumn{6}{|l|}{ Aldehydes } \\
\hline 2-Propenal & 1419 & $0.140 \pm 0.01 \mathrm{a}$ & $0.093 \pm 0.02 b$ & $0.051 \pm 0,03 b$ & nd \\
\hline Benzaldehyde & 941 & $0.509 \pm 0.02 \mathrm{a}$ & $0.315 \pm 0.02 b$ & $0.150 \pm 0.04 \mathrm{c}$ & $0.165 \pm 0.02 \mathrm{c}$ \\
\hline Cinnamaldehyde & 1234 & $0.064 \pm 0.02$ & $0.017 \pm 0.03 b$ & nd & nd \\
\hline 4-Methylcinnamaldehyde & 1185 & $0.016 \pm 0.02$ & nd & nd & nd \\
\hline 2-Furancarboxaldehyde & 1108 & nd & nd & nd & $0.132 \pm 0.05$ \\
\hline
\end{tabular}

*Means \pm SD within a row with no common superscript differ $(P<0,05)$.

Nd, not detected; RI, retention index using alkane series (C8 to C20) under the same chromatographic conditions; HEL, Hatay earllactation; KEL, Kilis early lactation; HLL, Hatay late lactation; KLL, Kilis late lactation. 
Table III. Changes in volatile compounds ( $\mathrm{mg}^{100 \mathrm{~g}^{-1}}$, mean) of Kilis breed goat milk from Hatay and Kilis locations during both lactation period $(\mathrm{df}=9)$.

\begin{tabular}{|c|c|c|c|c|c|c|c|c|}
\hline & \multicolumn{2}{|c|}{ Hatay } & \multicolumn{2}{|c|}{ Kilis } & \multirow[b]{2}{*}{ SEM } & \multirow[b]{2}{*}{$\mathbf{L}$} & \multirow[b]{2}{*}{$\mathbf{L P}$} & \multirow[b]{2}{*}{ LxLP } \\
\hline & $\mathbf{E L}$ & $\mathbf{L L}$ & EL & $\mathbf{L L}$ & & & & \\
\hline 3-methylindole & 0.84 & 1.77 & 0.26 & 0.81 & 2.24 & 0.89 & 0.02 & 0.86 \\
\hline N-ethyl-1.3-dithioisoindoline & 0.75 & 1.09 & 0.75 & 1.47 & 1.86 & $<0.01$ & 0.01 & 0.01 \\
\hline Total indoles & 1.59 & 2.86 & 1.01 & 2.28 & & & & \\
\hline$\alpha$-pinene & 7.00 & 2.00 & 15.80 & 2.50 & 1.81 & 0.02 & $<0.01$ & 0.04 \\
\hline dl-limonene & 4.00 & 1.90 & 3.70 & 2.70 & 0.55 & 0.68 & 0.01 & 0.31 \\
\hline$\beta$-phellandiene & 2.00 & 2.20 & 1.90 & 2.50 & 0.14 & 0.24 & 0.01 & 0.18 \\
\hline Cymene & 3.10 & 0.80 & 3.90 & 2.50 & 0.65 & 0.09 & 0.01 & 0.49 \\
\hline n-terpene & 0.82 & 1.60 & 1.00 & 1.10 & 0.17 & 0.25 & 0.02 & 0.07 \\
\hline$\alpha$-Iron & 0.30 & 0.07 & 0.28 & 0.19 & 0.05 & 0.39 & 0.02 & 0.27 \\
\hline Camphene & 0.46 & 0.01 & 0.78 & 0.27 & 0.31 & 0.39 & 0.18 & 0.92 \\
\hline Total terpenes & 17.68 & 8.58 & 27.36 & 11.76 & & & & \\
\hline 2-Octanone & 0.56 & 0.87 & 0.58 & 0.91 & 0.08 & 0.73 & $<0.01$ & 0.89 \\
\hline 4-Nonanone & 0.53 & 0.87 & 0.55 & 1.00 & 0.14 & 0.54 & $<0.01$ & 0.61 \\
\hline Furanone & 0.62 & 0.48 & 0.10 & 0.06 & 0.05 & 0.02 & 0.01 & $<0.01$ \\
\hline 3-Buten-2-one & 0.05 & 0.51 & 0.45 & 0.14 & 0.29 & 0.96 & 0.80 & 0.22 \\
\hline Total ketones & 1.76 & 2.73 & 1.68 & 2.11 & & & & \\
\hline Benzaldehyde & 0.48 & 0.26 & 0.70 & 0.28 & 0.19 & 0.53 & 0.12 & 0.62 \\
\hline Benzoicacid & 0.39 & 0.37 & 0.36 & 0.5 & 0.67 & 0.52 & 0.47 & 0.30 \\
\hline Capricacid & 1.50 & 1.70 & 0.38 & 0.76 & 0.34 & 0.01 & 0.42 & 0.84 \\
\hline Total carbocylic acids & 1.78 & 2.07 & 0.74 & 1.26 & & & & \\
\hline Styrene & 1.10 & 2.00 & 1.00 & 0.90 & 0.29 & 0.05 & 0.19 & 0.13 \\
\hline Benzene.ethenylmethyl & 3.00 & 1.10 & 1.90 & 2.00 & 0.41 & 0.83 & 0.05 & 0.03 \\
\hline 1-ethenyl-4-ethyl- benzene & 2.00 & 1.10 & 1.80 & 1.60 & 0.31 & 0.65 & 0.09 & 0.25 \\
\hline 1.3-diethenyl benzene & 0.26 & 0.06 & 2.10 & 0.15 & 0.46 & 0.08 & 0.05 & 0.10 \\
\hline Total aromatic hydrocarbons & 6.36 & 4.26 & 6.80 & 4.65 & & & & \\
\hline 2-Octanol & 16.00 & 20.60 & 13.90 & 20.50 & 1.60 & 0.51 & $<0.01$ & 0.52 \\
\hline 4-Nonanol & 21.90 & 28.40 & 19.20 & 28.40 & 2.39 & 0.57 & $<0.01$ & 0.58 \\
\hline Total alcohols & 37.90 & 49.00 & 33.10 & 48.90 & & & & \\
\hline
\end{tabular}

EL, Early lactation; LL, Late lactation; L, Location; LP, Lactation period; SEM, Standard error of the mean.

study, the total ketone amount was higher for the $5.73 \%$ (Kilis) with respect to the $4.24 \%$ (Hatay) fat sample.

The highest amount of benzaldehyde has detected in milk from the early lactation period from Kilis, and the amount of five ketone compounds decreased during lactation, with the exception of 2-furancarboxaldehyde. However, even at low concentrations, aldehydes significantly contribute to the aroma of the milk (VazquezLandaverde et al., 2005).

Carboxylic acids are precursors of other aroma compounds, such as methyl ketones, alcohols, lactones, aldehydes and esters (Collins et al., 2003; Delgado et al., 2011). The amounts of carboxylic acid at the early and late lactation periods were higher in milk collected from Kilis. Previous studies have found that medium-chain fatty acids contribute to the goaty aroma (Silanikove et al., 2010), such as hexanoic (C6:0) and capric (C10:0) acid, while others have reported that octanoic acid has a rancid and pungent odour (Salles et al., 2002). Acetic acid was present in the late lactation period both locations and can be associated with the slightly tarty taste of Ibores cheese (Delgado et al., 2011). The amounts of benzoic and capric 
acid in milk from Hatay were relatively low in the early lactation period (Table II). Lauric acid may be the reason for bitter, rancid and unclean flavours (Clark and Mora Garcia, 2017). In milk from the early lactation period and from Kilis, the lauric acid content was $0.052 \mathrm{mg} 100 \mathrm{~g}^{-1}$. In a previous study, the amounts of hexanoic (caproic), octanoic, decanoic (capric) and dodecanoic (lauric) acids differed between Nubian and Alpine goat breeds, with Kilis goats presenting more of each of these aromatic compounds (Attaie et al., 1993).

Four aromatic hydrocarbons (styrene, benzene-ethyl methyl, 1-ethyl-4-ethyl benzene and 1.3-diethyl benzene) of the 18 components identified in milk from the two different locations were determined in both lactation periods. Aromatic hydrocarbons were identified in the milk samples, of which styrene and benzene-ethyl methyl were the most abundant ones. The levels of aromatic hydrocarbons were lower in milk from Kilis, while styrene and benzene-ethyl methyl were higher in milk from Hatay.

Ethanol, 2-octanol and 4-nonanol increased significantly $(P<0.05)$ throughout the lactation period in both locations. Secondary alcohols are formed by enzymatic reduction (alcoholdehydrogenase) of the corresponding methyl ketones (Molimard and Spinnler, 1996), and the increase in alcohols may be due to a reduction of grasses and an increase in the plant diversity over time (Fedele et al., 2005). Sant'Ana et al. (2019) have found 1-butanol, 1-hexanol and maltol in Sannen X American Alpine goat milk and suggested that these compounds are responsible for fruity and herbaceous flavours. Kilis goats can consume a wide range of plants due to their agility, mobile upper lips and tendency to assume a bipedal stance, apart from their higher salivary secretion and urea recycling capacity. The development of the salivary glands allows even the consumption of forage crops with bitter taste (MorandFehr, 1991). In cheese production, the milk type affects the volatile profile of cheeses (Delgado et al., 2011).

\section{CONCLUSIONS}

The composition of the milk from Kilis goats was significantly affected by lactation period and location. Milk from goats reared in Kilis showed a better profile in terms of total solids, fat, protein, unsaturated fat, alcohol, ketones and carboxylic acids when compared to milk from Hatay. Adequate feeding strategies for milk goats are important to improve the nutritional value of the milk and to increase economic gains. The volatile acid profile of milk varies depending on the origin of the animal.

\section{ACKNOWLEDGMENTS}

The authors thank Mustafa Cagrı Ucuk and Zeynel Gocmez (Eastern Mediterranean Agriculture Research Institute) for technical assistance.

\section{Statement of conflict of interest}

The authors have declared no conflict of interest.

\section{REFERENCES}

Agaoglu, O.K. and Ertugrul, O., 2012. Assessment of genetic diversity, genetic relationship and bottleneck using microsatellites in some native Turkish goat breeds. Small Rumin. Res., 105: 53-60. https://doi.org/10.1016/j.smallrumres.2011.12.005

Anonymous, 2018. Yerli Hayvan Irk Ve Hatlarının Tescili Hakkında Tebliğ Tebliğ No: 2004/39, Resmi Gazete Tarihi: 12.12.2004, Sayıs1: $25668 . \quad$ https://kms.kaysis.gov.tr/Home/ ter/35576? AspxAutoDetectCookieSupport=1 Kilis Keçisi (Ek:RG-22/04/2006-26147) (date of access 03.04.2019) In Turkish.

Anonymous, 2019. Kilis cografi yapl. https:// www.google.com/search?q=www.kilis.gov. tr $\% 2$ Fcografi-yapiandie $=$ utf- 8 andoe $=$ utf- 8 (date of access 13.04.2019) In Turkish

Alonso, L., Fontecha, J., Lozada, L., Fraga, M.J. and Juarez, M., 1999. Fatty acid composition of caprine milk: Major branched-chain and trans fatty acids. J. Dairy Sci., 82: 878-884. https://doi.org/10.3168/ jds.S0022-0302(99)75306-3

Alvarenga, T.I.R.C., Chen, Y., Furusho-Garcia, I.F., Perez,J.R.O., and Hopkins D.L., 2015. Manipulation of omega-3 PUFAs in lamb: Phenotypic and genotypic views. Comp. Rev. Fd. Sci. Fd. Saf., 14: 189-204. https://doi.org/10.1111/1541-4337.12131

Aslantas, O., Ozyoruk, F., Pınar, D. and Gungor, B., 2005. Serological survey for caprine arthritis-encephalitis virus in Damascus and Kilis goats in Hatay, Turkey. Rev. Méd. Vét., 156: 402-404.

Attaie, R., Richter, R.L. and Reine, A.H., 1993. Low molecular weight branched-chain and n-chain fatty acids in caprine and bovine colostrum. J. Dairy Sci., 76: 62-69. https://doi.org/10.3168/jds.S00220302(93)77323-3

Avondo, M., Bonanno, A., Pagano, R.I., Valenti, B., Di Grigoli, A., Alicata, M.L., Galofaro, V. and Pennisi, P., 2008. Milk quality as affected by grazing time of day in Mediterranean goats. J. Dairy Res., 75: 4854. https://doi.org/10.1017/S0022029907003019

Bauman, D.E. and Griinari J.M., 2003. Nutritional 
regulation of milk fat synthesis. Annu. Rev. Nutr., 23: 203-227. https://doi.org/10.1146/annurev. nutr.23.011702.073408

Bernard, L., Rouel, J., Leroux, C., Ferlay, A., Faulconnier, Y., Legrand, P. and Chilliard, Y., 2005. Mammary lipid metabolism and milk fatty acids secretion in Alpine goats fed vegetable lipids. $J$. Dairy Sci., 88: 1478-1489. https://doi.org/10.3168/ jds.S0022-0302(05)72816-2

Boutoial, K., Rovira, S., García, V., Ferrandini, E. and López, M.B., 2012. Influence of feeding goats with thyme and rosemary extracts on the physicochemical and sensory quality of cheese and pasteurized milk. In: Goats: Habitat, breeding management. Nova Science Publisher, New York, USA, pp. 45-54.

Boutoial, K., Ferrandini, E., Rovira, S., García, V. and López, M.B., 2013. Effect of feeding goats with rosemary (Rosmarinus officinalis spp.) by product on milk and cheese properties. Small Rumin. Res., 112: 147-153. https://doi.org/10.1016/j. smallrumres.2012.12.002

Cais-Sokolinska, D., Wojtowski, J., Pikul, J., Danków, R., Majcher, M., Teichert, J. and Bagnicka, E., 2015. Formation of volatile compounds in kefir made of goat and sheep milk with high polyunsaturated fatty acid content. J. Dairy Sci., 98: 6692-6705. https://doi.org/10.3168/jds.2015-9441

Calderon, I., De Peters, E.J., Smith, N.E. and Franke, A.A., 1984. Composition of goat's milk: Changes within milking and effects of a high concentrate diet. J. Dairy Sci., 67: 1905-191. https://doi. org/10.3168/jds.S0022-0302(84)81523-4

Carnicella, D., Dario, M., Ayres, M.C.C., Laudadio, V. and Dario, C., 2008. The effect of diet, parity, year and number of kids on milk yield and milk composition in Maltese goat. Small Rumin. Res., 77: 71-74. https://doi.org/10.1016/j. smallrumres.2008.02.006

Casey, N.H. and Van Niekerk, W.A., 1988. The Boer goat. I. Origin, adaptability, performance testing, reproduction and milk production. Small Rumin. Res., 1: 291-302. https://doi.org/10.1016/09214488(88)90056-9

Cetin, Y., Sagcan, S., Gungor, O., Ozyurtlu, N., and Uslu, B.A., 2009. Effects of CIDR-G and melatonin implants, and their combination on the efficacy of oestrus induction and fertility of Kilis goats. Reprod. Dom. Anim., 44: 659-662. https:// doi.org/10.1111/j.1439-0531.2007.01043.x

Chen, B., Grandison, A.S. and Lewis, M.J., 2017. Best use for milk- A review. II-Effect of physiological, husbandry and seasonal factors on the physicochemical properties of bovine milk. Int. J. Dairy Technol., 70: 155-164. https://doi. org/10.1111/1471-0307.12355

Clark, S. and Mora Garcia, M.B., 2017. A 100-Year Review: Advances in goat milk research. J. Dairy Sci., 100: 10026-10044. https://doi.org/10.3168/ jds.2017-13287

Collins, Y.F., McSweeney, P.L.H., and Wilkinson, M.G., 2003. Lipolysis and free fatty acid catabolism in cheese: A review of current knowledge. Int. Dairy J., 13: 841-866. https://doi.org/10.1016/S09586946(03)00109-2

Costa, W.K.A., Souza, E.L., Beltrao-Filho, E.M., Vasconcelos, G.K.V., Santi-Gadelha, T., Gadelha, C.A.A., Franco, O.L., Queiroga, R.C.R.E. and Magnani, M., 2014. Comparative protein composition analysis of goat milk produced by the Alphine and Saanen breeds in Northeastern Brazil and related antibacterial activities. PLoS One, 9: 1-8. https://doi.org/10.1371/journal.pone.0093361

Daskiran, I., Savas, T., Koyuncu, M., Koluman, N., Keskin, M., Esenbuga, N., Konyali, A., Cemal, I., Gule, S., Elmaz, O., Kosum, N., Dellal, G. and Bingol, M., 2018. Goat production systems of Turkey: Nomadic to industrial. Small Rumin. Res., 163: 15-20. https://doi.org/10.1016/j. smallrumres.2017.10.001

Delgado, F.J., González-Crespo, J., Cava, R. and Ramírez, R., 2011. Formation of the aroma of a raw goat milk cheese during maturation analysed by SPME-GC-MS. Fd. Chem., 129: 1156-1163. https://doi.org/10.1016/j.foodchem.2011.05.096

Fedele, V., Rubino, R., Claps, S., Sepe, L. and Morone, G., 2005. Seasonal evolution of volatile compounds content and aromatic profile in milk and cheese from grazing goat. Small Rumin. Res. 59: 273-279. https://doi.org/10.1016/j.smallrumres.2005.05.013

Greyling, J.P.C., Mmbengwa, V.M., Schwalbach, L.M.J. and Muller,T., 2004. Comparative milk production potential of indigenous and Boer goats under two feeding systems in South Africa. Small Rumin. Res., 55: 97-105. https://doi.org/10.1016/j. smallrumres.2003.11.014

Guo, M., Park, Y.W., Dixon, P.H., Gilmore, J.A. and Kindstedt, P.S., 2004. Relationship between the yield of cheese (Chevre) and chemical composition of goat milk. Small Rumin. Res. 52: 103-107. https://doi.org/10.1016/S0921-4488(03)00247-5

Ha, J.K. and Lindsay, R.C., 1993. Release of volatile branched-chain and other fattyacids from ruminant milk fats by various lipases. J. Dairy Sci., 76: 
677-690. https://doi.org/10.3168/jds.S00220302(93)77391-9

Hayaloglu, A.A., Cakmakci, S., Brechany, E.Y., Deegan, K.C. and McSweeney, P.L.H., 2007. Microbiology, biochemistryand volatile composition of Tulum cheese ripened in goat's skin or plastic bags. $J$. Dairy Sci., 90: 1102-1121. https://doi.org/10.3168/ jds.S0022-0302(07)71597-7

Haenlein, G.F.W., 2004. Goat milk in human nutrition. Small Rumin. Res., 51: 155-163. https://doi. org/10.1016/j.smallrumres.2003.08.010

Iriadam, M., 2007. Variation in certain hematological and biochemical parameters during the peri-partum period in Kilis does. Small Rumin. Res., 73: 54-57. https://doi.org/10.1016/j.smallrumres.2006.11.001

Le Doux, M., Rouzeau, A., Bas, P. and Sauvant, D., 2002. Occurrence of trans-C18:1 fatty acid isomers in goat milk: Effect of two dietary regimens. $J$. Dairy Sci., 85: 190-197. https://doi.org/10.3168/ jds.S0022-0302(02)74067-8

Liu S., Zhang, R., Kang, R., Meng, J. and Ao, C., 2016. Milk fatty acids profiles and milk production from dairy cows fed different forage quality diets. Anim. Nutri., 2: 329-333. https://doi.org/10.1016/j. aninu.2016.08.008

Martin, B., Verdier-Metz, I., Buchin, S., Hurtaud, C. and Coulon, J.B., 2005. How do the nature of forages and pasture diversity influence the sensoryquality of dairy livestock products? Anim. Sci., 81: 205212. https://doi.org/10.1079/ASC50800205

Mestawet, T.A., Girma, A., Ådnøy, T., Devold, T.G., Narvhus, J.A. and Vegarud, G.E., 2012. Milk production, composition and variation at different lactation stages of four goat breeds in Ethiopia. Small Rumin. Res., 105: 176-181. https://doi. org/10.1016/j.smallrumres.2011.11.014

Molimard, P. and Spinnler, H., 1996. Review: Compounds involved in the flavour of surface mold-ripened cheeses: origins and properties. $J$. Dairy Sci., 79: 169-184. https://doi.org/10.3168/ jds.S0022-0302(96)76348-8

Morand-Fehr, P., 1991. Goat nutrition. Pudoc, Wageningen. III (EAAP publication, ISSN 00712477 ; no. 46)

Muelas, R., Martí de Olives, A., Romero, G., Díaz, J.R., Sayas-Barberá, M.E. and Sendra, E., 2018. Evaluation of individual lactic acid bacteria for the fermentation of goat milk: Quality parameters. LWT Fd. Sci. Technol., 98: 506-514. https://doi. org/10.1016/j.lwt.2018.09.005

Prache S., Cornu, A., Berdagu'e, J.L. and Priolo, A., 2005. Traceability of animal feeding diet in the meat and milk of small ruminants. Small Rumin. Res., 59: 157-168. https://doi.org/10.1016/j. smallrumres.2005.05.004

Prasad, H., Tewari, H.A. and Sengar, O.P.S., 2005. Milk yield and composition of the beetal breed and their crosses with Jamunapari, Barbari and Black Bengal breeds of goat. Small Rumin. Res., 58: 195-199. https://doi.org/10.1016/j.smallrumres.2004.10.002

Raynal-Ljutovac K., Lagriffoul, G., Paccard, P., Guillet, I. and Chilliard, Y., 2008. Composition of goat and sheep milk products: An update. Small Rumin. Res., 79: 57-72. https://doi.org/10.1016/j. smallrumres.2008.07.009

Sant'Ana, A.M.S., Bessa, R.J.B., Alves, S.P., Medeiros, A.N., Costa, R.G., de Sousa, Y.R.F., Bezerril, F.F., Malveira Batista, A.S., Madruga, M.S. and Queiroga, R.C.R.E., 2019. Fatty acid, volatile and sensory profiles of milk and cheese from goats raised on native semiarid pasture or in confinement. Int. Dairy J., 91: 147-154. https://doi.org/10.1016/j. idairyj.2018.09.008

Salles, C., Sommerer, N., Septier, C., Issanchou, S., Chabanet, C., Garem, A. and Le Quéré, J.L., 2002. Goat cheese flavor: Sensory evaluation of branchedchain fatty acids and small peptides. J. Fd. Sci., 67: 835-841.https://doi.org/10.1111/j.1365-2621.2002. tb10686.x

SAS., 1999. Statistical analysis system user's guide. SAS Institute, Inc. Cary, NC.

Schreurs, N.M., Lane, G.A., Tavendale, M.H., Barry, T.N. and McNabb, W.C., 2008. Pastoral flavour in meat products from ruminants fed fresh forages and its amelioration by forage condensed tannins. Anim. Feed Sci. Technol., 146: 193-221. https:// doi.org/10.1016/j.anifeedsci.2008.03.002

Schwendel, B.H., Wester, T.J., Morel, P.C.H., Tavendale, M.H., Deadman, C., Shadbolt, N.M. and Otter, D.E., 2014. Invited review: Organic and conventionally produced milk-An evaluation of factors influencing milk composition. J. Dairy Sci., 98: 721-746. https://doi.org/10.3168/jds.20148389

Silanikove, N., 2000. The physiological basis of adaptation in goats to harsh environments. Small Rumin. Res., 35: 181-193. https://doi.org/10.1016/ S0921-4488(99)00096-6

Silanikove, N., Leitner, G., Merin, U., and Prosser, C.G., 2010. Recent advances in exploiting goat's milk: quality, safety and production aspects. Small Rumin. Res., 89: 110-124. https://doi.org/10.1016/j. smallrumres.2009.12.033

Talpur, F.N., Bhanger, M.I. and Memon, N.N., 2009. 
Milk fatty acid composition of indigenous goat and ewe breeds from Sindh, Pakistan. J. Fd. Compost. Anal., 22: $\quad 59-64$. https://doi.org/10.1016/j. jfca.2008.09.005

Tasdemir, U., Agaoglu, A.R., Kaymaz, M. and Karakas, K., 2011. Ovarian response and embriyo yield of Angora and Kilis goats given the day 0 protocol for superovulation in the non-breeding season. Trop. Anim. Hlth. Prod., 43: 1035-1038. https://doi. org/10.1007/s11250-011-9802-8

Vazquez-Landaverde, P.A., Velazquez, G., Torres, J.A. and Qian, M.C., 2005. Quantitative determination of thermally derived off-flavor compoundsin milk using solid-phase microextraction and gas chromatography. J. Dairy Sci., 88: 3764-3772. https://doi.org/10.3168/jds.S0022-0302(05)730629

Verruck, S., Dantas, A. and Prudencio, E.S. 2019. Functionality of the components from goat's milk, recent advances forfunctional dairy products development and its implications on human health. J. Funct. Fds., 52: 243-257. https://doi. org/10.1016/j.jff.2018.11.017

Yurchenko, S., Sats, A., Tatar, V., Kaart, T., Mootse, H. and Jõudu, I., 2018. Fatty acid profile of milk from Saanen and Swedish Landrace goats. $F d$. Chem., 254: 326-332. https://doi.org/10.1016/j. foodchem.2018.02.041 